\title{
Assessing the Effect of Different Water Table Depths on Water Use, Yield and Water Productivity of the Okra Crop
}

\author{
NAZAR GUL*, MUHAMMAD MUNIR BABAR**, ASADULLAH SARKI***, IRFAN AHMED SHAIKH***, \\ AND MUNIR AHMED MANGRIO***
}

RECEIVED ON 04.05.2017 ACCEPTED ON 21.08.2017

\begin{abstract}
An experimental study was carried out on a Lysimeter with the aim of partially meeting WRs (Water Requirements) of the Okra crop through SWT (Shallow Water Table) while maintaining the SWT at various levels below the ground surface. Under the study, CWR (Crop Water Requirement), yield, water productivity, salt accrual and contribution of SWTs towards meeting the CWR are assessed. The study was designed in accordance with the principles of CRD (Complete Randomized Design) with three treatments and four replications. The treatments; viz. $T_{1}, T_{2}$, and $T_{3}$ consisted of maintaining the WTDs (Water Table Depths) at 45, 60 and $75 \mathrm{~cm}$, respectively, below the ground surface. The crop was irrigated with a good quality water having $\mathrm{EC}_{\mathrm{w}}=0.50 \mathrm{dS} \mathrm{m}^{-1}$ and $\mathrm{pH}=7.3$. The results of the study showed that the crop consumed the maximum amount of water under $T_{1}$ treatment, followed by $T_{2}$ and then by $T_{3}$ treatment. Accordingly, the contribution of SWTs towards the CWR is 94.8, 93.2 and 42.9\% of the total CWR under the $T_{1}, T_{2}$, and $T_{3}$ treatments, respectively. Maximum yield is attained under $T_{3}$ treatment, followed by $T_{2}$ treatment and then by $T_{1}$ treatment. Likewise, maximum water productivity is achieved under $T_{3}$ treatment, followed by $T_{2}$ treatment and then by $T_{1}$ treatment. The dry bulk density $\left(\rho_{d}\right)$ of the soil, under $T_{1}$ and $T_{2}$ treatments, increased slightly; however, it remained unchanged under the $T_{3}$ treatment. The $\mathrm{EC}_{\mathrm{se}}$ (Electrical Conductivity) of the soil increased, whereas, the $\mathrm{pH}$ value of the soil decreased under all the treatments. Statistically, significant difference $(p<0.05)$ is observed in CWR, yield, water productivity, contribution of SWT towards crop water use, plant height and weight of the Okra pod; whereas, the difference in $\rho_{\mathrm{d}}, \mathrm{EC}_{\mathrm{se}} \mathrm{pH}$ and length of the pod is observed as not significant ( $\left.\mathrm{p}>0.05\right)$ under the three treatments. Accordingly, to make profitable use of SWTs, improve WUE and productivity, and maintain soil fertility, the depth of SWT be controlled at $75 \mathrm{~cm}$ for growing of the Okra crop. Adapting to this guideline will help in availing the maximum contribution of SWTs towards meeting the CWR and achieve the larger aim of water conservation.
\end{abstract}

Key Words: Lysimeter, Water Table Depths, Crop Water Requirement, Water Productivity, Yield, Okra Crop.

\section{INTRODUCTION}

W

Tth increasing population, urbanization and industrialization, competition for water is increasing worldwide. The gap between water supply and demand is also widening with every passing day. Population increase is pressing for additional food and domestic water supplies, consumer goods and

Corresponding Author (E-Mail: mmunirbabar.uspcasw@faculty.muet.edu.pk)

* Drainage and Reclamation Institute of Pakistan, Tando Jam.

** US-Pakistan Centres for Advanced Studies in Water, Mehran University of Engineering * Technology, Jamshoro.

*** $\quad$ Sindh Agriculture University, Tando Jam.

Mehran University Research Journal of Engineering \& Technology, Volume 37, No. 1, January, 2018 [p-ISSN: 0254-7821, e-ISSN: 2413-7219] 
water for environmental needs from the existing water resources. Worldwide, more than $40 \%$ of food production depends on supplements by irrigation waters [1]. In Pakistan, agriculture consumes more than $93 \%$ of good quality water [2,3]. Due to increasing agricultural activities in the country, the gap between water supply and demand has widened manifolds. Thus, there is a dire need of fresh water resources to meet the ever-increasing demand of various users. Given the scenario of not having much potential for additional water resources to be developed, the only option remains to manage the available water resources sensibly and adapt to best management practices.

Since, agriculture is the major consumer of fresh water resources, any effort towards improving WUE in this sector will be worthwhile. Increasing WUE through improved irrigation technologies, crops, and improved productivity of lands by maintaining soil fertility will be a complimentary approach towards managing irrigation waters and saving waters for other logical uses. Currently, throughout the world, the average irrigation efficiency, resulting from surface irrigation techniques, range from 30-50\%. Poor irrigation efficiency offers an opportunity for improvement that will result in additional water supply for cultivating extra lands or for other uses; however, this must not be at the cost of negatively impacting yields.

SGW (Shallow Groundwater) is an important resource that can be harnessed to irrigate crops through subsurface irrigation technique and thereby reduce the gap between water supply and demand [4]. Depending on the quality of SGW and type of the crop grown, this technique can be used to meet fully or partially the WR of crops. So far, numerous studies have been conducted regarding the use of SGW as an additional source of irrigation water [5]. Using the SGW resource to supplement the crop water demand is affected by the level of WTD, groundwater quality, crop growth stage, crop salt tolerance, irrigation frequency and application depth, and whether the crop is seasonal or perennial. Literature reveals that various investigators have investigated the impact of SWTs on crop yield, land and water environment, water saving and crop water productivity.

Nosetto et. al. [6] reported that, normally, the rise of the WT and its getting into the root-zone profile has adverse impacts on crop health and thereby on yield as well. According to Liu and Luo [7], the problem of waterlogging induced by SWTs can be addressed by curtailingdown the amount of irrigation waters, and instead using the SWT to meet the crop water demand; however, they suggested that maintaining the WT at optimum level is essential to make its profitable use without degrading the soil environment. Karimov et. al. [8] while using HYDRUS1D numerically simulated the groundwater contribution towards the ET (Evapotranspiration) need of wheat crop and also the salt concentration in the root-zone profile; they found that SWTs increased the salt concentration within the root-zone profile. They argued that groundwater potential can be favorably used for subsurface irrigation, which will also help in lowering down the WTDs and help in to achieve water saving if proper cropping pattern and WTDs are managed.

Mejia et. al. [9] obtained maximum yield for corn and soybean crops under artificially controlled WTDs at 0.5 and $0.75 \mathrm{~m}$ in comparison to free drainage treatment, in which WT level was $\geq 1.0 \mathrm{~m}$ below the ground surface. Khan et al. [10] observed that the sugarcane yield was highest if the WTD ranged between 1.2-1.9 $\mathrm{m}$, and the yield reduced if the WTD was shallower than $1.0 \mathrm{~m}$ or deeper than $2.0 \mathrm{~m}$ from the ground surface. Nosetto et. al. [6] found that when the WTD ranged from 1.4-2.45, 1.22.2 and 0.7-1.65 m; the maize, soybean, and wheat crops resulted in maximum yield, respectively; they also concluded that crop yield decreases if the WTD is shallower than these limits. Zhu et. al. [11] investigated 
the impact of WTD on soybean yield and concluded that the soybean yield reduced if WTD was shallower or deeper than $2 \mathrm{~m}$.

Mueller et. al. [12] observed that highest WUE can be achieved by controlling the WTDs at the optimum level. Kahlown et. al. [13] found that the wheat and sunflower used 100 and $80 \%$ of their water consumption, respectively, through subsurface irrigation when WTD was maintained at $0.5 \mathrm{~m}$. Liu and Luo [7] observed that the wheat used $65 \%$ of its WR from the groundwater if the WTD is maintained between 0.4-1.5 m; moreover, they also observed that the surface and subsurface water productivities are enhanced and these are proportional to decrease in WTD. Huo et. al. [14] found that the wheat crop consumed $29 \%$ of its water demand from subsurface waters when the WTD is maintained at $1.5 \mathrm{~m}$. They also observed that the contribution of subsurface irrigation helps in lowering down the WT. Ayars et. al. [1] while reviewing the feasibility of groundwater use in irrigated agriculture argued that SGW of good quality can be exploited and managed for crop water needs with the predominant factor of proper crop selection. Xu et. al. [15] found that if the WTD is shallower than the $1.0 \mathrm{~m}$, then the salt concentration in root-zone profile increases thereby yields decrease; for optimum growth of wheat, they suggested that WTD be maintained between 1.0-1.5 m.

The geographical area of Sindh province ofPakistan is 14.09 Mha, nearly 5.60 Mha of which is under cultivation and 5.96 Mha is the land not accessible for farming, whereas the land occupied by forests is 1.04 Mha and the land under cultural waste is 1.49 Mha [16]. Due to flatter topography of the area, the rise of the river bed, use of conventional irrigation techniques, high temperatures, and meager rainfall, the province is suffering from twin problems of water-logging and salinity. Of the total area of province, about $30 \%$ is waterlogged and saline, which poses threat to food security and sustainability of agriculture [17]. In 1999, about 2.2 Mha of the land has WTD ranging between 0-1.5 m below the ground surface; in the year 2001, the area then drastically reduced to about 0.26 Mha due to drought conditions in the province. In 2003, the area under SWT again rose to 2.7 Mha and since then it is continuously rising [18]. It's worthwhile to note that, in the area, before the inception of irrigation network, the WT remained deeper than $30 \mathrm{~m}$. However, after the introduction of canal irrigation system, the WT has risen-up significantly and at present, it varies between 1.5-9 $\mathrm{m}$ below the ground surface [19]. According to Kahlown and Azam [20], normally in Sindh province, the WTD remains within $1.5 \mathrm{~m}$ range in an area of about 1.622.03 Mha of the irrigated land. Basharat [21] reported that the water-logged area in the province ranges from 1.5-3.5 Mha. Thus, in the light of the statistics presented above, there lies a great potential in the province to harness the SGW resources as a means of supplementing the CWR through subsurface irrigation method to grow various crops. However, this requires conducting research to determine the optimal WTD for any specific crop so that crop water productivity is maximized and environmental health of the soil is not endangered.

Therefore, studies to grow crops under SWTs need to be conducted. This warrants the determination of CWR for crops under varying depths of WT in vadose zone to avoid over-irrigation. The study of WTs under open field conditions is difficult and unreliable as many causative factors are not under control and accurate observations are very difficult, whereas the Lysimeter is an ideal instrument to simulate prevailing conditions and obtain the proper solution of the problems. The present study is designed to conduct a lysimetric study to assess the effect of different WTDs on water use of Okra crop, yield, and crop water productivity and status of salinity in rootzone and thereby assess the potential of SGW to meet the CWRs. 
Okra (Hibiscus Esculentus L.) belongs to the family of Malvaceae [22]. Pakistan is the second largest producer of Okra, and in Sindh, this crop is grown throughout the year. It is an important source of vitamin A, B, and C and is also rich in protein, carbohydrates, fats, minerals, iron, and iodine. In Pakistan, this crop, locally known as 'Bhindi', is widely grown in Punjab and Sindh provinces. It's estimated area under cultivation is about $2.21 \times 10^{5} \mathrm{ha}$, yielding about $2.86 \times 10^{6}$ Tons of green pods annually [23]; whereas the average world production of this crop is about 12.035 M Tons annually [24].

\section{MATERIALS AND METHOD}

\subsection{Site Description and Experimental Design}

The study was conducted at the DRIP (Drainage and Reclamation Institute of Pakistan) of the PCRWR (Pakistan Council for Research in Water Resources), during 2016. The Institute is located at $25^{0} 25^{\prime} 10.6^{\prime \prime}$ North Latitude and $68^{\circ} 31^{\prime}$ '35.2' East Longitude and at an average altitude of $12.8 \mathrm{~m}$ above the mean sea level. The experiment was conducted on a non-weighing type Lysimeter with 12 circular chambers. Each chamber has an internal diameter of $45 \mathrm{~cm}$. The experiment was designed in accordance with the principles of CRD with three treatments $\left(\mathrm{T}_{1}, \mathrm{~T}_{2}\right.$, and $\mathrm{T}_{3}$ ) and four replications. The $\mathrm{T}_{1}, \mathrm{~T}_{2}$, and $\mathrm{T}_{3}$ treatments consisted of maintaining the WTDs at 45, 60 and $75 \mathrm{~cm}$, respectively.

\subsection{Description of the Lysimeter}

The Lysimeter at the DRIP campus is drainage type madeup of RCC (Reinforced Cement Concrete). Figs. 1-3 show the schematic diagram of one of the Lysimeter chamber, the layout of the experimental site and a picture of the Lysimeter at the site. Operational dimensions of each chamber are $0.159 \mathrm{~m}^{2} \mathrm{x} 0.90 \mathrm{~m}\left(=0.143 \mathrm{~m}^{3}\right)$. The width of the passage leading between two rows of the chambers is $1.46 \mathrm{~m}$, which is about $1.52 \mathrm{~m}$ below the ground surface. To allow installation and monitoring of instruments at all levels in full depth of all chambers, a staircase is fitted from the ground level leading towards the bottom of the passage. To monitor WT position, individual piezometers of $1.27 \mathrm{~cm}$ diameter are installed in each Lysimeter chamber. For the purpose of the present study, all chambers of the Lysimeter were filled with silt loam soil; since silt loam soil is the predominant soil texture available in the Lower Indus Basin [25].

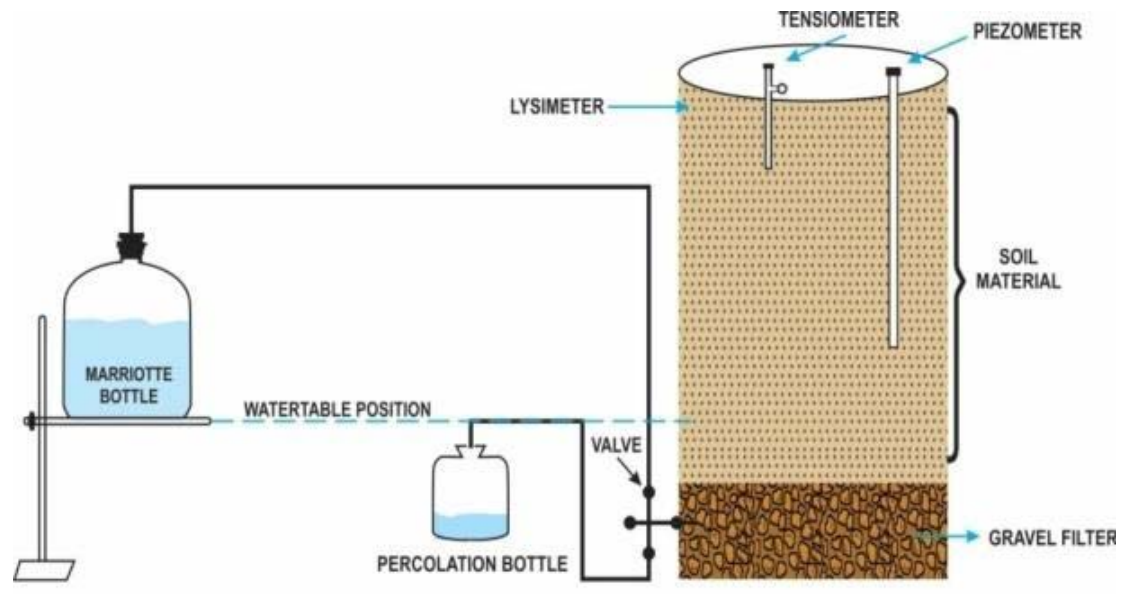

FIG. 1. SCHEMATIC DIAGRAM OF LYSIMETER CHAMBER

Mehran University Research Journal of Engineering \& Technology, Volume 37, No. 1, January, 2018 [p-ISSN: 0254-7821, e-ISSN: 2413-7219] 


\subsection{Data Collection, Inputs and Experimental Procedure}

Before sowing of the crop, four soil samples at varying depths (0-15, 16-30, 31-45 and 46-60 cm) from each Lysimeter chamber were collected to analyze the pre-cropsowing soil status. Similarly, after harvest of the crop same number of soil samples were collected from each chamber to analyze the post-harvest soil status. Altogether, ninety-six soil samples were collected and analyzed for soil $\mathrm{EC}_{\mathrm{se}}$ and $\mathrm{pH}$. The data pertaining to $\mathrm{EC}_{\mathrm{se}}$, $\mathrm{pH}$, and $\rho_{\mathrm{d}}$ is presented in Table 1 , section 3.1. Likewise, irrigation water samples were collected to assess its $\mathrm{EC}_{\mathrm{w}}$ and $\mathrm{pH}$ values. During the entire period (March 14 - July 1, 2016) of study, good quality irrigation water with $\mathrm{EC}_{\mathrm{w}}$ value of $0.50 \mathrm{dS} \mathrm{m}^{-1}$ and $\mathrm{pH}$ of 7.3 was applied.

Before sowing of the Okra crop in the Lysimeter, a soaking dose of $75 \mathrm{~mm}$ of irrigation water was applied to all the chambers through surface irrigation (flooding) technique. This water was applied just to allow germination of the seed. Later, no any irrigation water was added to $\mathrm{T}_{1}$ and $\mathrm{T}_{2}$ treatments through surface irrigation technique for the entire crop period, except in the case of $\mathrm{T}_{3}$ treatment.
Throughout the cropping period, soil moisture content was monitored and thereby irrigation water was scheduled. For this purpose, a tensiometer was installed in each chamber; its penetration depth was changed with stage of the crop growth. The penetration depths were kept at 15,30 and $45 \mathrm{~cm}$ up till $25^{\text {th }}, 55^{\text {th }}$ and $110^{\text {th }}$ day of the sowing period of the crop, respectively. Fig. 4 shows a picture of Lysimeter chambers and tensiometers at the site. When the soil moisture tension reached to $70 \mathrm{kPa}$, irrigation water was added to $\mathrm{T}_{3}$ treatment through surface technique [26] and for each irrigation exercise; $75 \mathrm{~mm}$ (11.85 liters) of water was applied. Any surplus water (drainage effluent) was collected in Jarry cans through the drainage outlets provided at the bottom of each Lysimeter chamber.

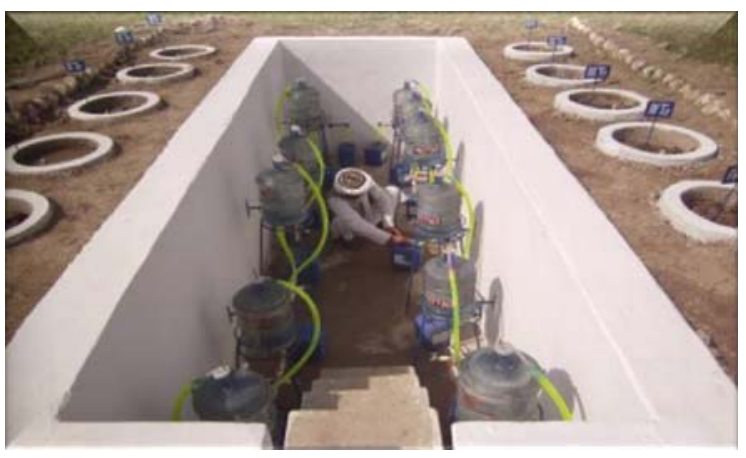

FIG. 3. LYSIMETER ARRANGEMENT AT THE EXPERIMENTAL SITE

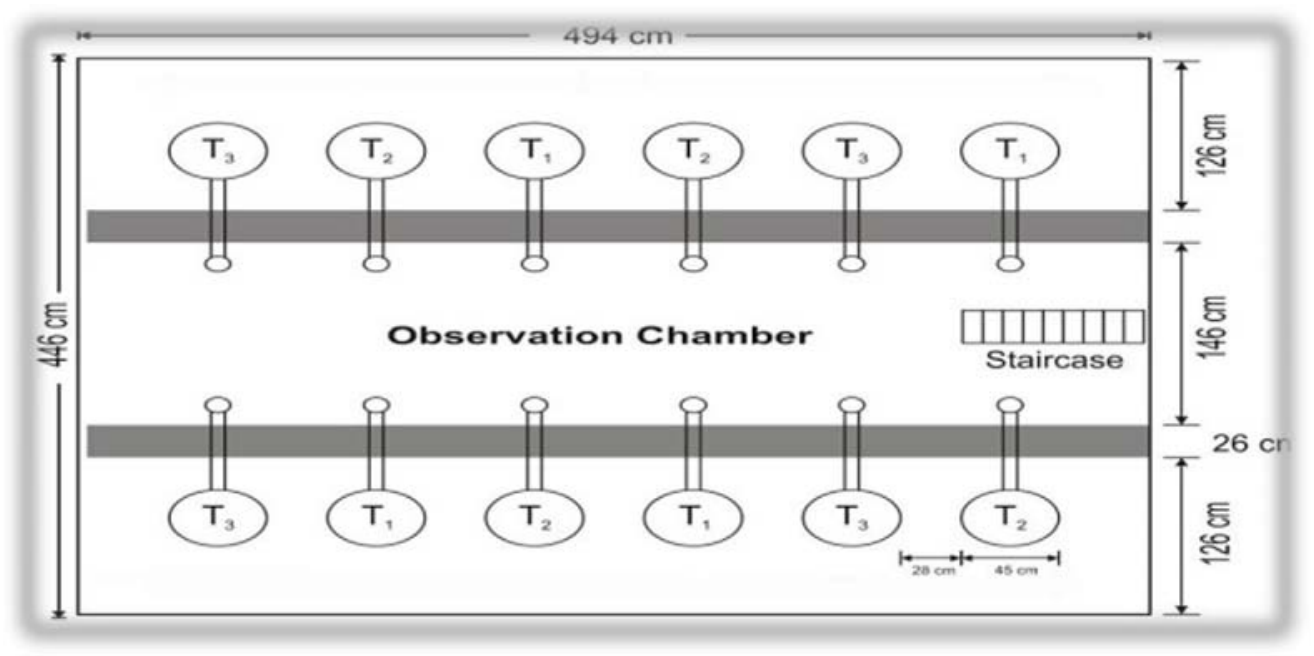

FIG. 2. LAYOUT OF THE LYSIMETER

Mehran University Research Journal of Engineering \& Technology, Volume 37, No. 1, January, 2018 [p-ISSN: 0254-7821, e-ISSN: 2413-7219] 
In each treatment, chemical fertilizer were applied @ 100120-0 NPK kg ha-1 [26]. The pesticides, imidacloprid, and emamectin benzoate were sprayed@ $39.52 \mathrm{ml} \mathrm{ha}^{-1}$ and $93.86 \mathrm{ml} \mathrm{ha}^{-1}$, respectively, as per recommendations made by Buriro et. al. [27].

The design WTDs of 45, 60 and $75 \mathrm{~cm}$ below the soil surface were maintained artificially in each Lysimeter chamber through mariotte bottles (Fig. 1). These bottles are individually installed to serve their respective chambers. The bottoms of the bottles are positioned in line with the design WTD levels and are connected to their respective chambers through pipes. Any drop in WT level in a Lysimeter chamber induces the flow of water from its respective bottle towards the chamber to maintain its design WT level. Any water deficiency in the bottles was compensated by re-filling the bottles to their previous levels. This procedure enabled to estimate the contribution of groundwater to meet the CWR through subsurface irrigation.

The water balance equation shown below is used to compute the CWR:

$\mathrm{CWR}=\mathrm{I}+\mathrm{S}+\mathrm{R}-\mathrm{D} \pm \mathrm{SMS}$

where, CWR represents CWR (mm), I denotes amount of surface irrigation water applied (mm), S stands for amount of water contributed through groundwater (subsurface irrigation) to meet CWR (mm), R refers to amount of effective rainfall (mm), D stands for the drainage effluent (mm) and SMS signifies the soil moisture storage, which is equal to the difference in soil moisture before the sowing and after the harvest of crop.

The water productivity of Okra crop under different treatments was also worked out using the following relationship [28]:

$$
\mathrm{CW}_{\mathrm{P}}=\frac{\mathrm{Y}}{\mathrm{WR}}
$$

where, $\mathrm{CW}_{\mathrm{p}}$ is crop water productivity $\left(\mathrm{kg} \mathrm{m}^{-3}\right), \mathrm{Y}$ represents the yield of the crop $\left(\mathrm{kg} \mathrm{ha}^{-1}\right)$ and WR- denotes the amount of total water consumption for crop production $\left(\mathrm{m}^{3} \mathrm{ha}^{-1}\right)$.

Agronomical parameters such as plant height, length, and weight of the pod were also measured and recorded under different WTD conditions [29]. As the crop reached to fruiting and marketable stage, the green pods of the crop were picked. All the collected data was statistically analyzed using the software, the Statistics 8.1.

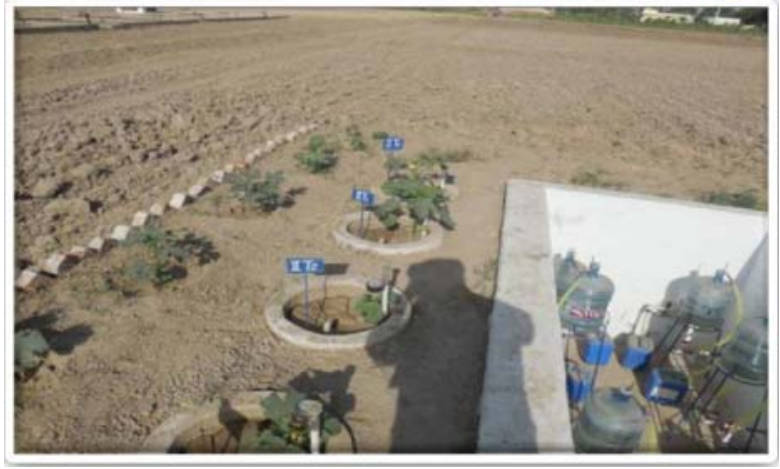

FIG. 4. ARRANGEMENT OF THE LYSIMETER CHAMBERS AND TENSIOMETERS AT SITE

TABLE 1. SHOWING EC se $_{\text {, }} \mathbf{p H}$, AND DRY BULK DENSITY OF THE SOIL

\begin{tabular}{|c|c|c|c|c|c|c|c|c|c|}
\hline \multirow{2}{*}{$\begin{array}{l}\text { WTD } \\
(\mathrm{cm})\end{array}$} & \multicolumn{3}{|c|}{ ECse $\left(\mathrm{dS} \mathrm{m}^{-1}\right)$} & \multicolumn{3}{|c|}{$\mathrm{pH}$} & \multicolumn{3}{|c|}{$\rho_{d}\left(\mathrm{~g} \mathrm{~cm}^{-3}\right)$} \\
\hline & $\mathrm{B}^{*}$ & $\mathrm{~A}^{* *}$ & Diff. & $\mathrm{B}^{*}$ & $\mathrm{~A}^{* *}$ & Diff. & $\mathrm{B}^{*}$ & $\mathrm{~A}^{* *}$ & Diff. \\
\hline 45 & 3.32 & 3.84 & $0.52 \mathrm{a}$ & 7.8 & 7.6 & $-0.2 a$ & 1.41 & 1.43 & $0.02 \mathrm{a}$ \\
\hline 60 & 3.47 & 3.81 & $0.34 a$ & 8.0 & 7.9 & $-0.1 \mathrm{a}$ & 1.40 & 1.41 & $0.01 \mathrm{ab}$ \\
\hline 75 & 3.15 & 3.42 & $0.27 \mathrm{a}$ & 7.7 & 7.6 & $-0.1 \mathrm{a}$ & 1.42 & 1.42 & $0.00 \mathrm{~b}$ \\
\hline
\end{tabular}

Mehran University Research Journal of Engineering \& Technology, Volume 37, No. 1, January, 2018 [p-ISSN: 0254-7821, e-ISSN: 2413-7219] 


\section{RESULTS AND DISCUSSION}

\subsection{Soil Properties}

Table 1 shows the average values of $\mathrm{EC}_{\mathrm{se}}, \mathrm{pH}$, and $\rho_{\mathrm{d}}$ of soil for the depths 0-15, 16-30, 31-45 and 46-60 cm. Table 1 , it can be seen that maximum increase in $\mathrm{EC}_{\text {se }}$ occurred under the shallower WTD $(45 \mathrm{~cm})$ as compared to deeper WTD $(75 \mathrm{~cm})$. These results also conform to the findings made by Karimov et. al. [8], Yuan yuan et. al. [30] and Xuet al. [15]. These investigators found that when the WTD was shallower than a certain specific level, salt concentration increased within the root-zone profile with the contributions for CWR made from SWTs. From Table 1 , it can also be seen that, after the conduct of experiment, the average soil $\mathrm{pH}$ value reduced by $0.2,0.1$ and 0.1 under $T_{1}, T_{2}$ and $T_{3}$ treatments, respectively. From Table 1 , it can also be seen that the average soil $\rho_{d}$, under $T_{1}$ and $\mathrm{T}_{2}$ treatments, increased by 0.02 and $0.01 \mathrm{~g} \mathrm{~cm}^{-3}$, respectively, but, it remained unchanged under $T_{3}$ treatment. Obviously, the maximum increase in the density occurred under $\mathrm{T}_{1}$ treatment. As a result of increase in salt concentration under the two treatments, $T_{1}$ and $T_{2}$, the $\rho_{d}$ value in these treatments also increased. Nevertheless, the differences in soil $\mathrm{EC}_{\mathrm{se}}, \mathrm{pH}$ and $\rho_{\mathrm{d}}$ are not significant $(\mathrm{P}>0.05)$.

\subsection{Crop Water Requirement}

Fig. 5 shows the WRs for the Okra crop during its various growth stages. WR for the crop is the lowest during its initial stage, while it increases sharply during the midstage and then it reaches to peak during the final growth stage; and thereafter, the WR reduces sharply during the final stage. Since during mid and final growth stages, the Okra plant begins flowering and pod formation and also due to high temperatures during the months of April and May, the CWR is high. These two factors contribute towards high CWR during mid and final growth stages.
The total CWRfor the Okra crop under $\mathrm{T}_{1}, \mathrm{~T}_{2}$, and $\mathrm{T}_{3}$ treatment is computed as 542, 488 and $405 \mathrm{~mm}$, respectively (Fig. 5); out of this the crop consumed 94.8, 93.2 and $42.9 \%$ of its water demand through subsurface irrigation, while the rest of the amount, i.e.5.2, 6.8 and $57.1 \%$ was supplemented through surface irrigation, respectively. Themaximum amount of water is consumed under the WTD of $45 \mathrm{~cm}$ followed by $60 \mathrm{~cm}$ and then 75 $\mathrm{cm}$. Since, at the initial stage of crop sowing, evaporation losses are dominant over the transpiration rate and also due to more moisture content available in the upper soil layers of $T_{1}$ and $T_{2}$ treatments than in $T_{3}$ treatment; therefore, higher values of CWR are observed in the former two treatments. The higher soil moisture contents, in $\mathrm{T}_{1}$ and $\mathrm{T}_{2}$ treatments than in $\mathrm{T}_{3}$ treatment, are due to relatively more upward flux of groundwater in the former two treatments than the later one. Similar results were also observed by Karimov et. al. [8], who found that the water requirements of crops increase with the rising WT levels. Shallower WTs (45 and $60 \mathrm{~cm}$ ) contributed more towards the CWR than the deeper WTD $(75 \mathrm{~cm})$. Similar results were also found by Ayars et. al. [1]; according to them contribution of groundwater towards the CWR is directly proportional to the level of WTD. Furthermore, Kahlownet al. [13] also confirm our results where wheat and sunflower crops consumed 100 and $80 \%$ of their water requirement through shallow WTD, respectively; provided the WTD is maintained at $0.5 \mathrm{~m}$. Likewise, according to Liu and Luo [7] and Huo et. al. [14], a significant amount of CWR can be met through shallower WTs. The difference in CWR under various WTDs is highly significant $(\mathrm{P}<0.05)$.

\subsection{Crop Yield}

Fig. 6 presents the crop yield obtained under different treatments. The yields under $T_{1}, T_{2}$, and $T_{2}$ treatments are 3405, 4101 and $5986 \mathrm{~kg} \mathrm{ha}^{-1}$, respectively. Maximum yield is acquired in the case of deeper WTD $(75 \mathrm{~cm})$ as

Mehran University Research Journal of Engineering \& Technology, Volume 37, No. 1, January, 2018 [p-ISSN: 0254-7821, e-ISSN: 2413-7219] 
compared to shallower WTDs (45 and $60 \mathrm{~cm}$ ).This might suggest that the shallower WTDs has excessively submerged the root-zone profiles and thereby reduced the amount of aeration. Similar results were also suggested by Nosetto et. al. [6], who in their study observed that as the WT level becomes shallower, the crop yield declines sharply due to water-logging and root anoxia.

The yield obtained under $T_{3}$ treatment increased by 43.2 and $31.5 \%$ as compared to yield acquired under $\mathrm{T}_{1}$ and $\mathrm{T}_{2}$ treatments, respectively; while comparing the yield obtained under $\mathrm{T}_{2}$ treatment with the $\mathrm{T}_{1}$ treatment, it increased by $17 \%$. Therefore, it can be concluded that the crop produced higher yields with deeper WTDs as compared to shallower WTDs as a result of better aeration in the root-zone. Xu et. al. [15] and Zhu et. al. [11] also support these findings. According to Zhu et. al. [11], crop yield increases rapidly with decreasing WTD from 0.2-2.0 m. Khan et. al. [10] also support similar opinion; according to them crop yield is maximum when the WTD ranges between 1.2-1.9 m, and if the WTD is shallower than $1.0 \mathrm{~m}$ or deeper than $2.0 \mathrm{~m}$ from the ground surface, the yield would reduce. Analysis of variance shows that there is a highly significant difference $(\mathrm{P}<0.05)$ in yield of the Okra crop under different WTDs.

\subsection{Water Productivity}

The water productivity of the Okra crop under $\mathrm{T}_{1}, \mathrm{~T}_{2}$, and $\mathrm{T}_{3}$ treatments are $0.63,0.84$ and $1.48 \mathrm{~kg} \mathrm{~m}^{-3}$, respectively (Fig. 7). Because of higher yield and minimum amount of water consumed by crop, higher water productivity are obtained with deeper WTDs. Huo et. al. [14], Liu and Luo [7] and Mueller et. al. [12] also support these findings. Analysis of variance shows that there is a highly significant difference $(\mathrm{P}<0.05)$ in water productivity of Okra crop under different WTDs.

\subsection{Agronomical Parameters}

During the study, agronomical parameters of the crop, such as the height of the plant, length, and weight of the Okra pod were also examined. The heights of the plant under $\mathrm{T}_{1}, \mathrm{~T}_{2}$, and $\mathrm{T}_{3}$ treatments area measured as

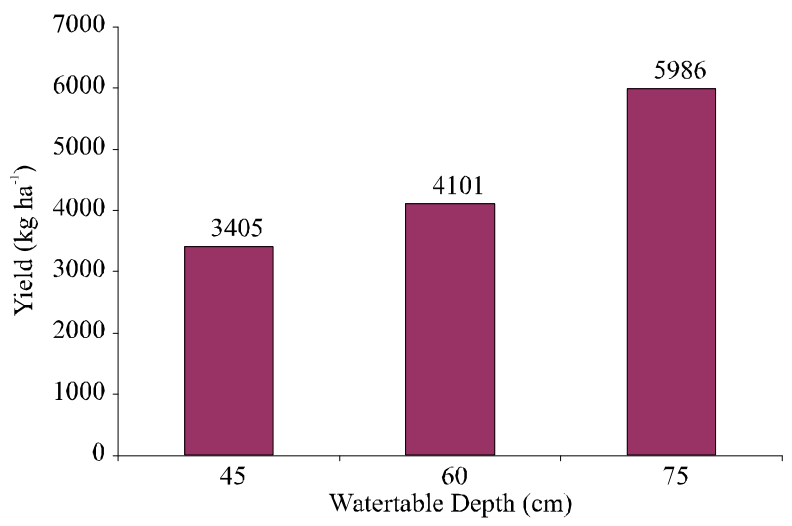

FIG. 6. YIELD OF OKRA CROP UNDER DIFFERENT WTDS

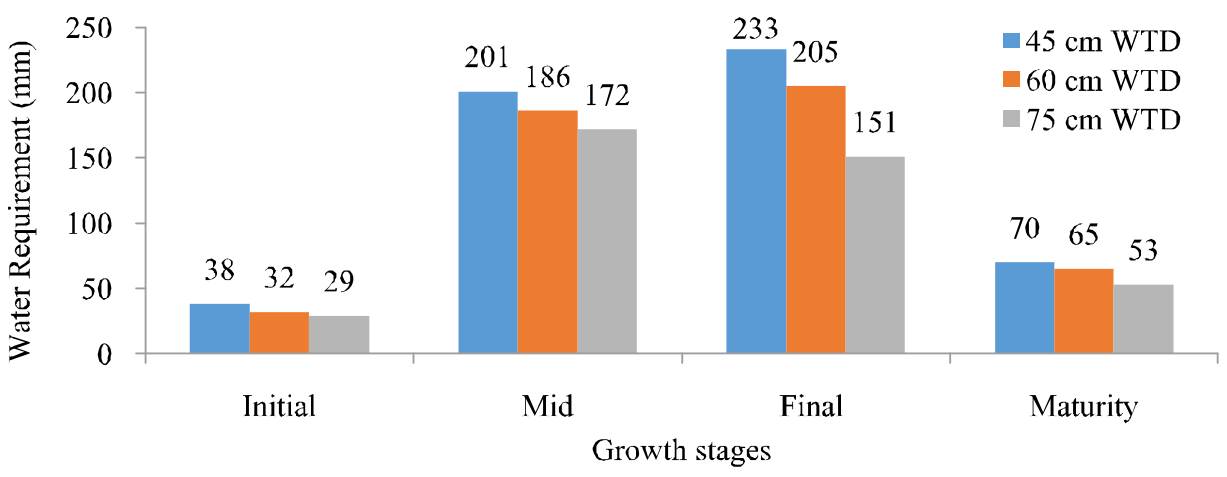

FIG. 5. WATER REQUIREMENTS FOR THE OKRA CROP W.R.T TO GROWTH STAGES

Mehran University Research Journal of Engineering \& Technology, Volume 37, No. 1, January, 2018 [p-ISSN: 0254-7821, e-ISSN: 2413-7219] 
57.25, 65.75 and $75.75 \mathrm{~cm}$, respectively (Fig. 8). Deeper WTDs resulted in higher plant heights, which is also in agreement with the results obtained by Nosetto et. al. [6]. Figs. 9-10 show comparative graphs of the length and weight of Okra pod acquired under different WTD conditions, respectively. The average length of the pod obtained under $\mathrm{T}_{1}, \mathrm{~T}_{2}$, and $\mathrm{T}_{3}$ were 9.64, 9.97 and 10.60 $\mathrm{cm}$, respectively; likewise, the weight of the pod was 7.18, 8.10 and 10.22 grams in the given order of treatments. Results show that deeper WTD produced longer and weighty pods as compared to shallower WTDs. Similar results were also reported by Nosetto et. al. [6]. There were significant differences $(\mathrm{P}<0.05)$ in plant height and weight, and non-significant difference $(\mathrm{P}>0.05)$ in length of the Okra pod under different WTD conditions.

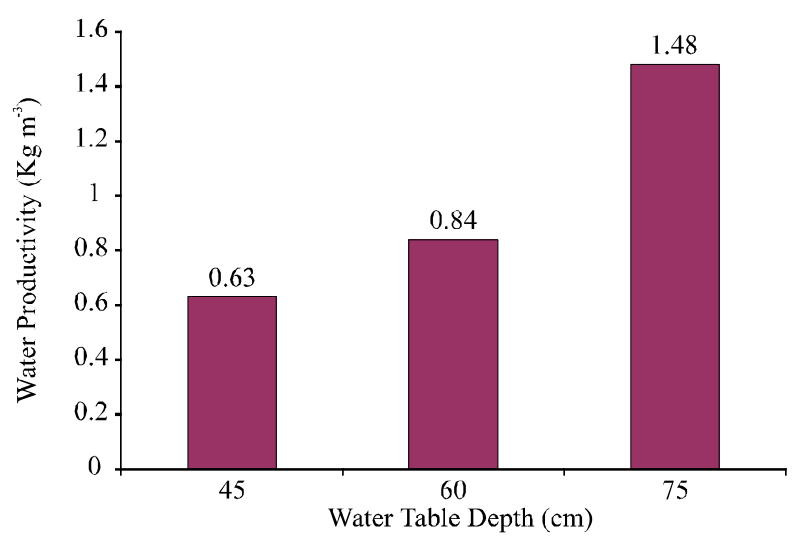

FIG. 7. WATER PRODUCTIVITY OF OKRA CROP UNDER DIFFERENT WTDS

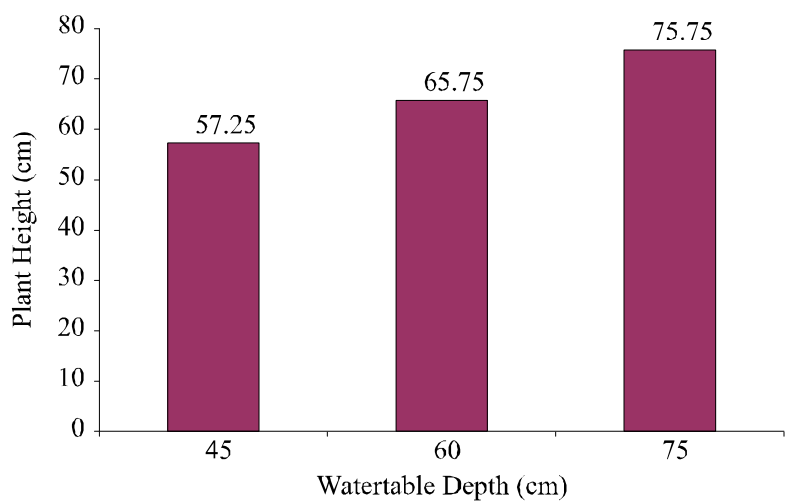

FIG. 8. PLANT HEIGHT OF OKRA CROP UNDER DIFFERENT WTDS

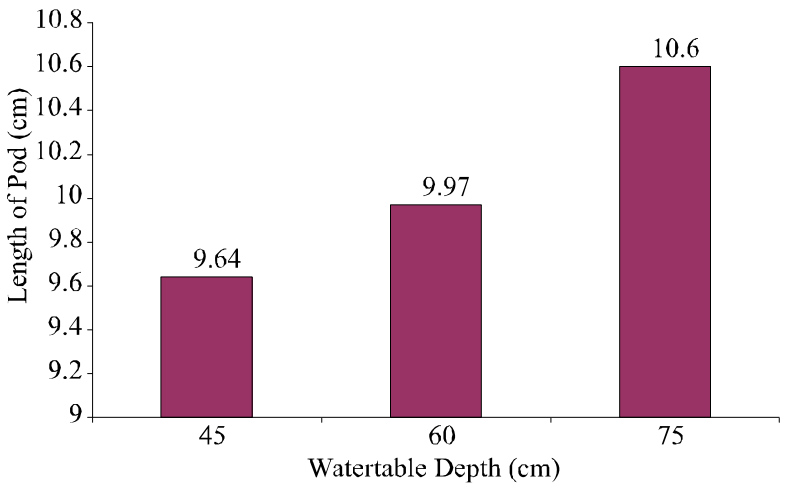

FIG. 9. LENGTH OF OKRA POD UNDER DIFFERENT WTDS

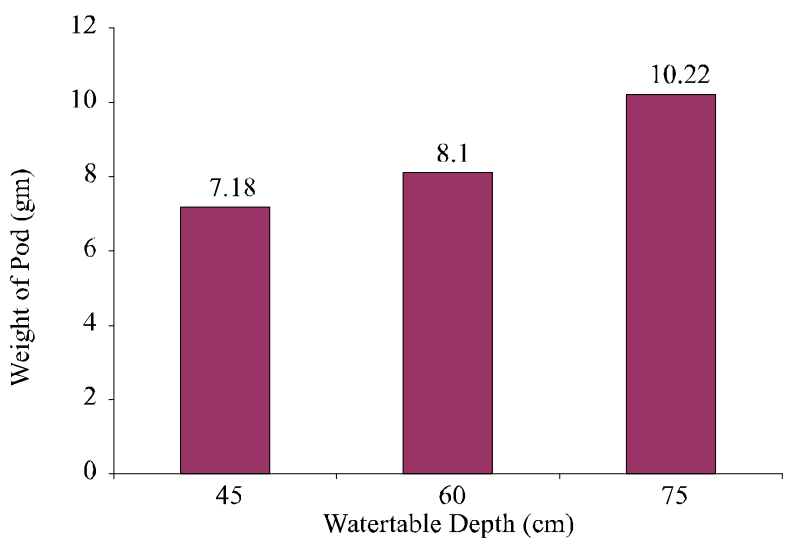

FIG. 10. WEIGHT OF OKRA POD UNDER DIFFERENT WTDS

\section{CONCLUSION}

It can be concluded that the contribution of SGW towards the water requirement of the Okra crop varies significantly under varying WTDs. When the WT levels were maintained at 45,60 and $75 \mathrm{~cm}$ below ground surface, the groundwater contributed 94.8, 93.2 and $42.9 \%$, respectively, of the total CWR for growing of the crop. The contribution of SGW reduced with falling WT levels. Under different WT levels, CWR varied considerably. The maximum amount of water is consumed under the WTD of $45 \mathrm{~cm}$ followed by $60 \mathrm{~cm}$ and then by $75 \mathrm{~cm}$. The yield of the Okra crop is also significantly affected by the varying levels of WTD. Maximum yield is attained under $\mathrm{T}_{3}$ treatment, followed by $\mathrm{T}_{2}$ and then by $\mathrm{T}_{1}$ treatment. Thus, the Okra crop is realized as water- 
logging sensitive crop, since its yield decreased considerably under shallower WTDs. The effect of varying WTDs on water productivity of the crop is also significantly realized. The water productivity of the crop reduced considerably with shallower WTDs $\left(\mathrm{T}_{1}\right.$ and $\mathrm{T}_{2}$ treatments). The agronomical parameters (biomass) of the crop were also realized higher with falling WTDs. Accordingly, to make profitable use of SWTs, improve WUE and productivity, and maintain soil fertility, the depth of SWT be controlled at $75 \mathrm{~cm}$ for growing of the Okra crop under silty loam soils. Adapting to this guide line will help in availing the maximum contribution of SWTs towards meeting the CWR and achieve the larger aim of water saving.

\section{ACKNOWLEDGEMENT}

The authors gratefully acknowledge the support of the Director In-Charge and supporting staff of the DRIP, Tando Jam of PCRWR, for their constant assistance in completing this piece of research work.

\section{REFERENCES}

Ayars, J.E., Christen E.W., Soppe, R.W., and Meyer, W.S., "The Resource Potential of In-Situ Shallow Groundwater Use in Irrigated Agriculture: A Review”, Irrigation Science, Volume 24, No. 3, pp. 147-160, 2006.

Latif, M., "Measures to Mitigate Impacts of Drought: Global Perspective and Conditions in Pakistan”, Proceedings of the National Symposium on Drought and Water Resources in Pakistan, Saeed, M.M, and Latif, M. (Editors), CEWRE, pp. 1-4, Lahore, Pakistan, March, 2002

[3] Mohyuddin, J., and Ahmed, S., "Evaluation of the Best Fertilizers Combination In order to Obtain Higher Crop Yields Under Normal and Saline Soil Conditions”, Pakistan Journal of Water Resources, Volume 12, No. 2, pp. 19-24, 2008.
[4] Ayars J.E., Hutmacher, R.B., Schoneman, R.A., Soope, R.W.O., Vail, S.S., and Dale, F., "Realizing the Potential of Integrated Irrigation and Drainage Water Management for Meeting Crop Water Requirements in Semi-Arid and Arid Areas”, Irrigation and Drainage Systems, Volume 13, No. 4, pp. 321-347, 1999.

[5] Ayars J.E., Hutmacher, R.B., Schoneman, R.A., Vail, S.S., and Pflaum, T., "Long-Term Use of Saline Water for Irrigation”, Irrigation Science, Volume 14, No. 1, pp. 27-37, 1993.

[6] Nosetto, M.D., Jobbagy, E.G., Jackson, R.B. and Sznaider, G.A., "Reciprocal Influence of Crops and Shallow Groundwater in Sandy Landscapes of the Inland Pampas”, Field Crop Research, Volume 113, No. 2, pp. 138-148, 2009.

Liu, T., and Luo, Y., "Effects of Shallow Water Tables on the Water Use and Yield of Winter Wheat under Rain-Fed Condition”, Australian Journal of Crop Science, Volume 5, No. 13, pp. 1692-1697, 2011.

[8] Karimov, A.K.,Simunek, J., Munir, A.H., Avliyakulov, M., and Forkutsa, I., "Effects of the Shallow Water Table on Water Use of Winter Wheat and Ecosystem Health: Implications for Unlocking the Potential of Groundwater in the Fergana Valley, Central Asia”, Agricultural Water Management, Volume 131, No. 1, pp. 57-69, 2014.

[9] Mejia, M.N., Madramootoo, C.A., and Broughton, R.S., "Influence of Water Table Management on Corn and Soybean Yields”, Agricultural Water Management, Volume 46, No. 1, pp. 73-89, 2000.

[10] Khan, G.D., Shah, M., Tariq, M., Khan, M.Z., and Naveedullah, "Impact of Water Table Depths on the Physical Properties of Salt Affected Soil and Yield of Sugarcane in Mardan SCARP Area”, Sarhad Journal of Agriculture, Volume 23, No. 2, pp. 351-356, 2008. Fang, X., and Yuan, F, "Effect of Water Table Depth on Growth and Yield of Soybean Yudou 16”, Journal of Hydrologic Engineering, Volume 18, No. 9, pp. 1070-1076, 2013. 
[12] Mueller, L., Behrendt, A., Schalitz, G., and Schindler, U., “Above Ground Biomass and Water Use Efficiency of Crops at Shallow Groundwater Tables in a Temperate Climate”, Agricultural Water Management, Volume 75, No. 2, pp. 117-136, 2005.

[13] Kahlown, M.A., Ashraf, M.,andHaq,Z., "Effect of Shallow Groundwater Table on Crop Water Requirements and Crop Yields”, Agriculture Water Management, Volume 76, No. 1, pp. 24-35, 2005.

[14] Huo, Z., Feng, S., Huang, G., Zheng, Y., Wang, Y., and Guo, P., "Effect of Groundwater Level Depth and Irrigation Amount on Water Fluxes at the Groundwater Table and Water Use of Wheat”, Irrigation and Drainage, 2011,http://dx. [DOI.org/10.1002/ird.685].

[15] Xu, X., Huang, G., Sun, C., Pereira, L.S., Ramos, T.B., Huang, Q., and Hao, Y., "Assessing the Effects of Water Table Depth on Water Use, Soil Salinity, and Wheat Yield: Searching for a Target Depth for Irrigated Areas in the Upper Yellow River Basin”, Agricultural Water Management, Volume 125C, pp. 46-60, 2013.

[16] GOP, "Land Utilization Statistics”, Bureau of Statistics, Government of Pakistan, Islamabad, 2009.

[17] Anonymous, "Salinity and Water-Logging”, Sindh Vision 2030, Planning and Development Department, Government of Sindh, pp. 1-230, 2007.

[18] Lashari, B.K., and Mahesar, M.A., "Potential for Improving Water and Agriculture Productivity in Sindh, Pakistan”, $16^{\text {th }}$ International Water Technology Conference, Istanbul, Turkey, pp. 1-12, 2012.

[19] Mangrio, M.A., Mirjat, M.S., Leghari, N., Buriro, R.A., Talpur, M.A., Shaikh, I.A., and Mirjat, M.U., "Evaluating Farmer's Perception and Technical Approach Regarding Groundwater Extraction in Lower Sindh”, Science International (Lahore), Volume 27, No. 1, pp. 371-476, 2015.
Kahlown, M.A., and Azam, M., "Individual and Combined Effect of Water-Logging and Salinity on Crop Yields in the Indus Basin”, Irrigation and Drainage, Volume 51, pp. 329-338, PCRWR, Islamabad, Pakistan, 2002, www.interscience.wiley.com, [DOI: 10.1002/ird.62].

Basharat, M., "Spatial and Temporal Appraisal of Groundwater Depth and Quality in LBDC Command: Issues and Options”, Pakistan Journal of Engineering and Applied Sciences, Volume 11, pp. 14-29, 2012.

[22] Naveed, A., Khan, A.A., and Khan, I.A., "Generation Mean Analysis of Water Stress Tolerance in Okra”, Pakistan Journal of Botany, Volume 41, No. 1, pp. 195-205, 2009.

Kashif, S.R., Yaseen, M., Arshad, M., and Ayub, M., "Response of Okra to Soil Given Encapsulated Calcium Carbide”, Pakistan Journal of Botany, Volume 40, No. 1, pp. 175-181, 2008.

[24] FAO, “Statistical Division Database”, 2011, http://www. Faostat.fao.org.

[25] Shaikh, M., and Yaseen, M., "Detailed Soil Survey of DRIP Campus Tandojam, Hyderabad”, Drainage and Reclamation Institute of Pakistan, Irrigation, Drainage and Flood Control Research Council, Report 11, Lib. pp. 919, 1980

[26] Firoz, Z.A., "Impact of Nitrogen and Phosphorus on the Growth and Yield of Okra in Hill Slope Condition”, Bangladesh Journal of Agriculture Research, Volume 34, No. 4, pp. 713-722, 2009.

Buriro, A.S., Khaskheli, A.M., and Jarwar, A.D., "Handbook of Safe and Efficient Use of Pesticides", Directorate-General of Agriculture Research, Sindh, Tandojam, Department of Agriculture, Government of Sindh, 2006.

[28] Majumdar, D.K., "Irrigation Water Management Principles and Practices”, Prentice Hall of India, Pvt. Ltd., pp. 487, New Dehli,2000. 
[29] Kaur, H., Chawla, N., and Pathak, M., "Effect of Different Seed Priming Treatments and Priming Duration on Biochemical Parameters and Agronomic Characters of Okra”, International Journal of Plant Physiology and Biochemistry, Volume 7, No. 1, pp. 1-11, 2015.
[30] Yuanyuan, H., Xu, X., Quanzhong, H., and Guanhua, H., "Modeling Soil Water-Salt Dynamics and Maize Yield Responses to Groundwater Depths and Irrigations”, Transactions of Chinese Society of Agricultural Engineering, Volume 30, No. 20, pp. 128-136, 2014.

Mehran University Research Journal of Engineering \& Technology, Volume 37, No. 1, January, 2018 [p-ISSN: 0254-7821, e-ISSN: 2413-7219] 